\title{
KESADARAN MEREK DAN PENGALAMAN MEREK TERHADAP PREFERENSI MEREK PADA PRODUK PARFUM MEREK VITALIS DI UNIVERSITAS TADULAKO
}

\author{
FATIKAHTUL ISLAMIAH \\ ELIMAWATY ROMBE \\ PONIRIN \\ Jurusan Manajemen, Fakultas Ekonomi, Universitas Tadulako \\ Email: fatikahtul.i@gmail.com
}

\begin{abstract}
The aim of this research is to determine the influence of brand awareness and brand experience on the brand preferences of Vitalis perfume in Tadulako University. The type of this research is explanatory. The population in this study focuses on students that consume Vitalis perfume in Tadulako University. The sampling technique applied is purposive sampling technique, with a total sample of 90 respondents. Data collection method is questionnaires. Method of analysis is path analysis. The results of the test show that brand awareness and brand experience have positive and significant influence on brand preference of Vitalis perfume in Tadulako University. Brand experience has positive and significant influence on brand preference of Vitalis perfume in Tadulako University.
\end{abstract}

Keywords: brand awareness, brand experience and brand preferences

\begin{abstract}
Abstrak
Penelitian ini bertujuan untuk mengetahui pengaruh kesadaran merek dan pengalaman merek terhadap preferensi merek pada produk parfum merek Vitalis di Universitas Tadulako. Jenis penelitian yang digunakan adalah eksplanatory research (penelitian penjelasan). Populasi dalam penelitian ini dikhususkan pada mahasiswi pengguna parfum merek Vitalis di Universitas Tadulako. Teknik penarikan sampel dalam penelitian ini menggunakan purposive sampling, dengan jumlah sampel sebanyak 90 responden. Pengambilan data menggunakan kuesioner. Metode analisis menggunakan analisis jalur (path analysis). Hasil pengujian menunjukkan bahwa variabel kesadaran merek berpengaruh positif dan signifikan terhadap preferensi merek pada produk parfum merek Vitalis di Universitas Tadulako, dan Variabel pengalaman merek berpengaruh positif dan signifikan terhadap preferensi merek pada produk parfum merek Vitalis di Universitas Tadulako.
\end{abstract}

Kata Kunci: Kesadaran Merek, Pengalaman Merek, dan Preferensi Merek

\section{Pendahuluan}

Dewasa ini, dengan melihat perkembangan merek parfum yang cukup tajam menjadi suatu hal yang wajar apabila penggunaannya menjadi kewajiban saat melakukan aktivitas apapun. Perkembangan merek parfum tidak terlepas pula dari era perkembangan tren dan mode. Sehingga baik produsen dan konsumen menginginkan terobosan baru dalam kehidupan sehari-harinya. Parfum adalah produk yang sudah tidak asing lagi dalam kehidupan sehari-hari. Apalagi saat ini aroma parfum yang ditawarkan sudah semakin beragam, baik yang dikhususkan untuk pria, wanita, ataupun untuk keduanya. Setiap orang memiliki aroma parfum yang digemarinya. Aroma dan wewangian setiap parfum menyimpan khas tersendiri bagi penggunanya, tak jarang parfum ini mampu menambah rasa percaya diri, semangat, dukungan, kenyaman dan rasa kehangatan.

Menurut Kotler dan Keller (2009:179) kesadaran merek adalah kemampuan untuk mengidentifikasi (mengakui atau mengingat) merek dalam kategori, dengan cukup rinci untuk melakukan pembelian. Pengakuan lebih mudah dicapai dibandingkan ingatan konsumen, berdasarkan pengertian tersebut sejauh manakah kesadaran mahasiswi di Universitas Tadulako untuk menempatkan parfum Vitalis dalam benaknya.

Brakus, Schmitt dan Zarantonello (2009) menyatakan bahwa pengalaman merek dimulai pada saat konsumen mencari produk, membeli, menerima pelayanan dan mengkonsumsi produk. Konsumen dengan preferensi atau selera yang baik dapat mengambil manfaat dari diferensiasi produk yang lebih banyak. Konsumen dapat membentuk preferensi mereka diantara merek dengan menggunakan atribut 
secara rasional untuk mencari merek yang menciptakan pengalaman melalui sensorik, emosional dan kreatif (Ebrahim, 2013).

Parfum dengan merek Vitalis yang diproduksi PT. Unza Vitalis di perkenalkan pada tahun 1986 dikenal sebagai rangkaian produk perawatan tubuh yang mengandung susu. PT. Unza Vitalis merupakan perusahaan global yang berpusat di Bengaluru India Barat dan salah satu perusahaan yang bergerak di bidang pembuatan kosmetik, di Indonesia PT. Unza Vitalis berfokus pada produk wewangian. Sebagai salah satu merek cologne wanita ternama (Sumber:Atikaw Susanti07.blogspot.com).

Vitalis adalah produk wewangian dan perawatan pribadi yang sukses dengan keharuman lembut yang selalu ditawarkannya untuk membantu memancarkan rasa percaya diri dalam mencapai kesuksesan, berani tampil dan menikmati hidup sepenuhnya. Parfum dengan merek Vitalis akan selalu menunjang penampilanmu. Sebagai contoh, salah satu parfum Vitalis Body Scent varian Blossom yang termasuk dalam 5 besar cologne pilihan konsumen (Sumber: AtikawnSusanti07.blogspot.com). Hal ini karena varian ini memiliki wangi yang tahan lama, dapat di aplikasikan langsung pada kulit, keharumannya tersebut menunjukkan kepribadian yang lembut mempesona dan sangat mendukung penampilan dalam meningkatkan rasa percaya dirinya dalam meraih mimpi, dalam kemasan yang dibuat sederhana serta elegan dan pancarkan pesonamu yang sesungguhnya (Sumber:

Alfaonline.com).

Berdasarkan pada sejumlah uraian yang telah dikemukakan di atas, maka penulis tertarik untuk mengadakan pengkajian secara lebih mendalam terhadap produk parfum merek Vitalis dalam karya tulis berbentuk skripsi dengan mengangkat judul penelitian sebagai berikut: "Kesadaran Merek Dan Pengalaman Merek Terhadap Preferensi Merek Pada Produk Parfum Merek Vitalis Di Universitas Tadulako", dengan tujuan:

1. Untuk menganalisis pengaruh kesadaran merek terhadap preferensi merek pada produk parfum merek Vitalis di Universitas Tadulako.

2. Untuk menganalisis pengaruh pengalaman merek terhadap preferensi merek pada produk parfum merek Vitalis di Universitas Tadulako.

\section{KAJIAN LITERATUR DAN PENGEMBANGAN HIPOTESIS Pengertian Pemasaran}

Assauri (2013:5) menyatakan pemasaran sebagai kegiatan manusia yang diarahkan untuk memenuhi dan memuaskan kebutuhan dan keinginan melalui proses pertukaran. Berdasarkan pengertian ini, pembahasan tentang pemasaran dapat lebih jelas dan terbatas dalam pembatasan tegas, terkait dengan kegiatan pemasaran yang berlaku universal. Sedangkan Menurut Kotler dalam Adisaputro (2014:5) pemasaran adalah proses sosial dimana individu-individu dan kelompokkelompok memperoleh apa yang mereka butuhkan (needs) dan inginkan (wants) melalui penciptaan, penawaran, dan pertukaran secara bebas dari barang dan jasa yang bernilai dengan pihak lain.

\section{Perilaku Konsumen}

Sunyoto (2015:4) mengartikan perilaku konsumen sebagai tindakan-tindakan yang dilakukan oleh individu, kelompok, atau organisasi yang berhubungan dengan proses pengambilan keputusan dalam mendapatkan, menggunakan barang-barang atau jasa ekonomis yang dapat dipengaruhi lingkungan. Sedangkan The American Association dalam Adam (2008:8) mendefinisikan perilaku konsumen sebagai interaksi dinamis antara afeksi \& kognisi perilaku dan lingkungannya dimana manusia melakukan kegiatan pertukaran dalam hidup mereka.

\section{Pengertian Merek}

Jika suatu merek tidak tersimpan dalam ingatan, merek tersebut tidak akan dipertimbangkan dalam benak konsumen. Inti merek yang hebat adalah produk yang hebat. American Marketing Association (AMA) dalam Kotler dan Keller (2009:258) merek adalah nama, istilah, tanda, lambang, atau desain, atau kombinasinya, yang dimaksudkan untuk mengidentifikasikan barang atau jasa dari salah satu penjual atau kelompok penjual dan bentuk mendiferensiasikannya mereka dari para pesaing. 


\section{Kesadaran Merek}

Alma (2014:158) menyatakan brand awareness adalah kesanggupan konsumen untuk mengenali suatu merek atau seberapa kuat merek tertanam dalam ingatan konsumen indikator-indikator kesadaran merek antara lain : 1) Kemampuan mengingat merek. 2)Kemampuan untuk mengingat dan mengenali model varian. Dan 3) Ciri khas merek (memahami informasi mengenai merek).

Rangkuti (2009:39) mendefinisikan kesadaran merek artinya adalah kesanggupan seseorang calon konsumen untuk mengenali atau mengingat kembali bahwa suatu merek merupakan kategori produk tertentu.

\section{Pengalaman Merek (Brand Experience)}

Merek yang baik akan menciptakan pengalaman yang baik. Perlu diketahui bahwa merek tidak dibesarkan oleh iklan tetapi oleh pengalaman merek, pelanggan mengetahui sebuah merek melalui kisaran hubungan dan interaksi yang luas (Kotler dan Amstrong, 2008:211). Sedangkan Brakus et al (2009) mendefinisikan brand experience sebagai sensasi, perasaan, kognisi dan tanggapan konsumen yang ditimbulkan oleh merek, terkait rangsangan yang ditimbulkan oleh desain merek, identitas merek, komunikasi pemasaran, orang dan lingkungan merek tersebut dipasarkan.

\section{Preferensi Merek}

Fongana (2009) brand preference seringkali ditemukan sebagai variabel yang langsung mempengaruhi keinginan konsumen untuk membeli brand. Preferensi merupakan kecenderungan akan sesuatu yang biasanya diperoleh setelah konsumen membandingkan sesuatu tersebut dengan sesuatu yang lainnya. Dengan demikian, brand preference merupakan kecenderungan seorang konsumen untuk menyukai sebuah merek dibandingkan yang lainnya sehingga akan membentuk keinginannya untuk membeli merek tersebut.

\section{Hubungan antara Kesadaran Merek dengan Prefensi Merek}

Gustafson dan Chabot dalam Purwanto, Hadiwidjojo dan Ratnawanti (2011) mengungkapkan preferensi konsumen terhadap merek terbentuk karena kesadaran merek dengan mengacu pada seberapa besar kesadaran konsumen dan konsumen potensial terhadap merek dan produk-produknya.

\section{Hubungan antara Pengalaman Merek dengan Prefensi Merek}

Pengalaman langsung adalah sumber informasi yang dapat dipercaya, yang membentuk preferensi dari kedua jenis pengalaman yang sama, Hamilton dan Thomson dalam Ebrahim (2013). Adanya preferensi yang melekat dari pengalaman sebelumnya telah dikemukakan oleh Simonson dalam Ebrahim (2013). Lebih lanjut, Heilman, Bowman dan Wright dalam Ebrahim (2013) menyelidiki evolusi preferensi konsumen baru ke pasar melalui pengalaman.

\section{Kerangka Pemikiran}

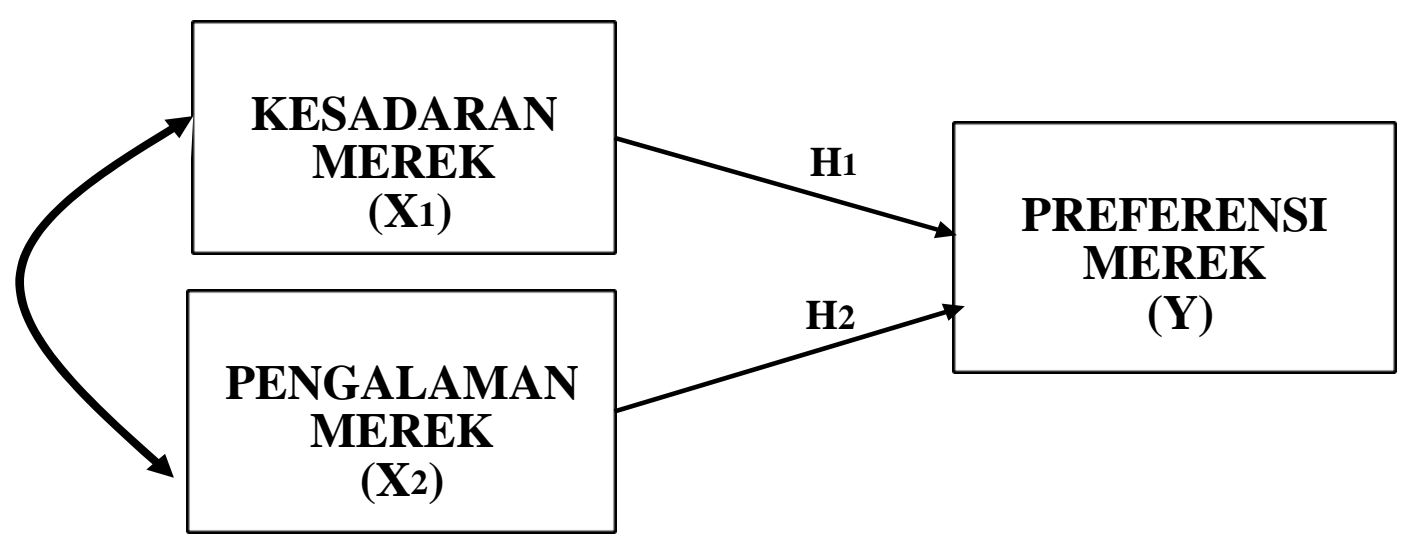

Gambar 1 kerangka pemikiran 


\section{Islamiyah F.}

\section{Hipotesis}

Berdasarkan rumusan masalah dan kajian pustaka yang dikemukakan maka dapat disusun hipotesis penelitian sebagai berikut:

1. Kesadaran merek berpengaruh signifikan terhadap preferensi merek pada produk parfum merek Vitalis di Universitas Tadulako.

2. Pengalaman merek berpengaruh signifikan terhadap preferensi merek pada produk parfum merek Vitalis di Universitas Tadulako.

\section{METODE PENELITIAN}

Jenis penelitian yang digunakan adalah eksplanatory research (penelitian penjelasan). Menurut Singarimbun, Masri dan Effendi (2008:5), explanatory research (penelitian penjelasan) adalah merupakan penelitian penjelasan yang menyoroti hubungan kausal antara variabel-variabel penelitian dan menguji hipotesis yang telah dirumuskan sebelumnya. Di dalam penelitian ini yang menjadi populasi ialah dikhususkan pada mahasiswi sebagai konsumen yang menggunakan parfum Vitalis selama kurun waktu penelitian yaitu diantara bulan November 2016 sampai dengan bulan Januari 2017 di Universitas Tadulako.

Jumlah sampel dalam penelitian ini merajuk pada Teori Roscoe dalam Sugiyono (2013:130) yaitu minimal 10 kali dari jumlah variabel yang diteliti (variabel independen + variabel dependen). Berdasarkan pertimbangan tersebut maka jumlah sampel ditentukan sebagai berikut:

$$
30 \times 3=90 \text { Responden }
$$

Adapun kriteria mahasiswi yang akan dijadikan sampel sebagai berikut: 1)Bersedia mengisi kuesioner dan mampu memahami isi kuesioner. 2) Pengguna parfum merek Vitalis. 3) Mahasiswi yang masih aktif kuliah. 4) Angkatan masuk 2013, 2014, 2015 dan 2016. Untuk mempermudah dalam pengumpulan data yang diperlukan dalam penelitian ini, dilakukan beberapa teknik pengumpulan data yaitu:

1. Dokumentasi adalah mencari data mengenai hal-hal atau variabel yang dapat berupa catatan, buku, majalah dan lain sebagainya.

2. Kuesioner adalah daftar pertanyaan tertulis yang telah dirumuskan sebelumnya yang akan di isi oleh responden yang menjadi konsumen produk parfum merek Vitalis.

3. Interview, yaitu pengumpulan data yang diperoleh melalui wawancara langsung kepada mahasiswi selaku konsumen produk parfum merek Vitalis.

Selanjutnya variabel penelitian mencerminkan karakteristik populasi yang ingin ditelaah. Operasional variabel dalam penelitian ini terdiri dari dua variabel, yaitu variabel independen $(X)$ dan variabel dependen $(\mathrm{Y})$. Untuk lebih jelasnya dapat dilihat rumusan berikut:

1. Kesadaran Merek

Alma (2014:158) indikator-indikator kesadaran merek terdiri atas:

1) Kemampuan mengingat merek.

2) Kemampuan untuk mengingat dan mengenali model varian. 3) Ciri khas merek (memahami informasi mengenai merek).

2. Pengalaman Merek (X2)

Dimensi pengalaman merek menurut Brakus et al (2009) terdiri atas:

1) Sensorik, menciptakan pengalaman melalui penglihatan, suara, sentuhan, bau, dan rasa.

2) Afeksi, pendekatan perasaan dengan mempengaruhi suasana hati, perasaan dan emosi.

3) Perilaku, menciptakan pengalaman secara fisik, pola perilaku dan gaya hidup.

4) Intelektual, menciptakan pengalaman yang mendorong konsumen terlibat dalam pemikiran seksama mengenai keberadaan suatu merek.

3. Preferensi Merek

Khan dan Bozzo (2012) indikator preferensi merek terdiri atas:

1) Lebih menyukai merek tertentu daripada merek lain.

2) Merek tertentu menjadi pilihan di antara semua merek.

3) Akan cenderung membeli merek tertentu di antara merek lain. 4) Akan lebih menggunakan merek tertentu daripada merek lain. 
Metode analisis data yaitu analisis inferensial. Zulganef (2013:165) analisis inferensial ialah teknik analisis data yang digunakan untuk menentukan sejauh mana kesesuaian antara hasil yang di peroleh dari sampel, dengan hasil dari populasi. Analisis yang digunakan adalah Analaisis Jalur (Path Analysis). Riduwan dan Kuncoro (2007:2) model path analysis digunakan untuk menganalisis pola hubungan antar variabel dengan tujuan untuk mengetahui pengaruh langsung maupun tidak langsung seperangkat variabel bebas (eksogen) terhadap variabel terikat (endogen) dan membicarakan hubungan sebab akibat.

Pengujian hipotesis (Uji t) dalam penelitian ini mengacu pada Riduwan dan Kuncoro (2007:118) untuk mengetahui signifikansi analisis jalur bandingkan antara nilai probabilitas 0,05 dengan nilai probabilitas Sig dengan dasar pengambilan keputusan sebagai berikut:

1. Jika nilai probabilitas 0,05 lebih kecil atau sama dengan nilai probabilitas $\mathrm{Sig}$ atau $(0,05 \leq \mathrm{Sig})$, maka Ho diterima dan Ha ditolak, artinya tidak signifikan.

2. Jika nilai probabilitas 0,05 lebih besar atau sama dengan nilai probabilitas Sig atau $(0,05 \geq \mathrm{Sig})$, maka Ho ditolak dan Ha diterima, artinya signifikan.

\section{HASIL DAN PEMBAHASAN}

Hasil Analisi Jalur (Path Analysis)

Berikut hasil analisis jalur berdasarkan hasil perhitungan analisis regresi menggunakan program SPSS For Windows Release 16.0, dapat dilihat pada Tabel 1 berikut:

Tabel 1 Hasil Perhitungan Analisis Regresi

\begin{tabular}{|c|c|c|c|c|c|}
\hline \multirow[t]{2}{*}{ Variabel } & \multicolumn{2}{|c|}{$\begin{array}{l}\text { Unstandardized Coefficients } \\
\text { (B) }\end{array}$} & \multirow{2}{*}{$\begin{array}{c}\begin{array}{c}\text { Standardized } \\
\text { Coefficients }\end{array} \\
\text { Beta }\end{array}$} & \multirow[t]{2}{*}{$\mathbf{T}$} & \multirow[t]{2}{*}{ Sig. } \\
\hline & $\mathbf{B}$ & Std. Error & & & \\
\hline (Constant) & 1,872 & 0,351 & - & 5,328 & 0,000 \\
\hline Kesadaran Merek $\left(\mathrm{X}_{1}\right)$ & 0,273 & 0,084 & 0,336 & 3,274 & 0.002 \\
\hline Pengalaman Merek $\left(\mathrm{X}_{2}\right)$ & 0,311 & 0,087 & 0,369 & 3.591 & 0.001 \\
\hline R Square $\left(\mathrm{R}^{2}\right)$ & 0.372 & \multirow{2}{*}{\multicolumn{4}{|c|}{ Jumlah data 82 Responden }} \\
\hline Adjusted R Square & 0.356 & & & & \\
\hline $\mathrm{R}$ & 0,610 & & & & \\
\hline
\end{tabular}

Berdasarkan hasil perhitungan analisis regresi yang terlihat pada Tabel 5.5 di atas, maka diperoleh persamaan struktural analisis jalur (path analysis) sebagai berikut:

Struktur: $\mathrm{Y}=\rho \mathrm{yx} 1+\rho \mathrm{yx} 2+\rho \mathrm{y} \epsilon 1$

$$
=0,336 \mathrm{x} 1+0,369 \mathrm{x} 2+0,792 € 1 \mathrm{R} 2 \mathrm{yx} 1 . \mathrm{x} 2
$$

atau $\mathrm{R}$ Square $(\mathrm{R} 2)=0.372$

Pyє $=\sqrt{ } 1-R 2 y x 1 . x 2=\sqrt{ } 1-0.372=\sqrt{ } 0,628=0,792$

Selanjutnya, nilai tersebut dimasukkan ke dalam kerangka hubungan kausal empiris antara X1 terhadap Y, X2 terhadap Y dapat dilihat pada Gambar 1 berikut ini: 


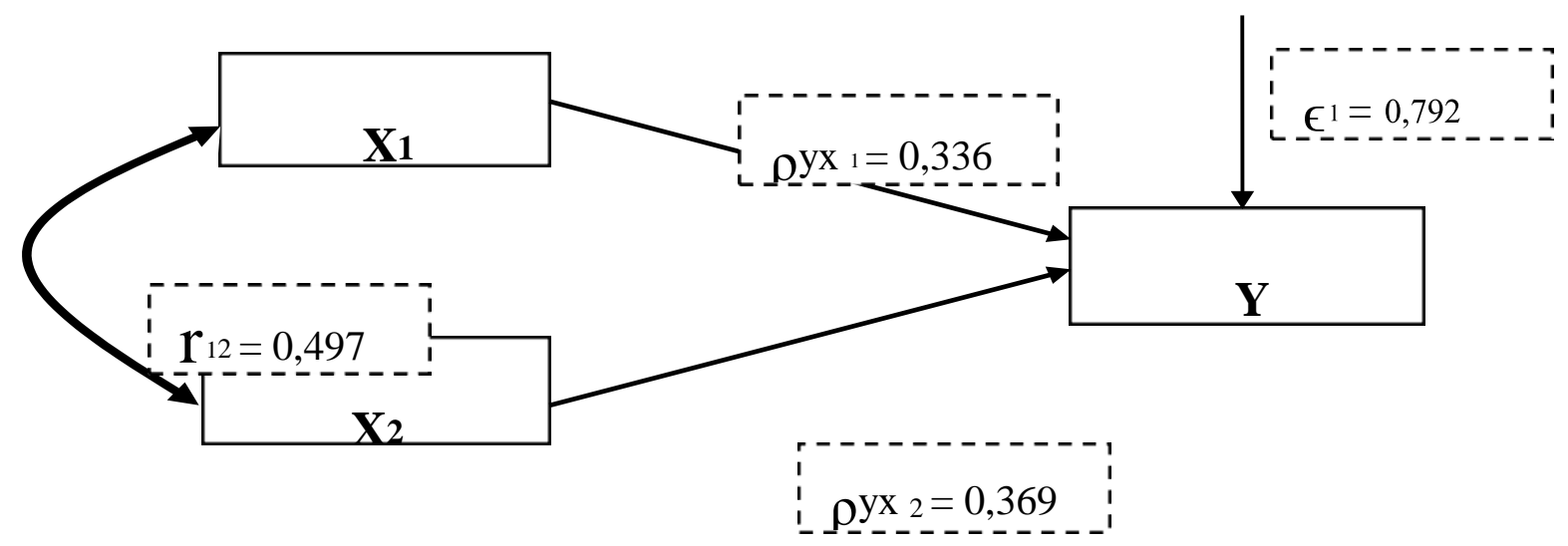

Gambar 1 Diagram Jalur Hubungan Kausal Empiris X1 Dan X2 Terhadap Y

Berdasarkan hasil perhitungan analisis jalur struktur tersebut, terlihat pada Gambar 5.8 di atas, maka memberikan informasi secara objektif sebagai berikut:

1. Besarnya pengaruh kesadaran merek $\left(\mathrm{X}_{1}\right)$ terhadap preferensi merek $(\mathrm{Y})$ adalah $0,336^{2}=$ 0,1129 atau $11,29 \%$.

2. Besarnya pengaruh pengalaman merek $\left(\mathrm{X}_{2}\right)$ terhadap preferensi merek $(\mathrm{Y})$ adalah sebesar $0,369^{2}=0,1362$ atau $13,62 \%$.

3. Besarnya pengaruh faktor-faktor lain yang tidak dapat dijelaskan dalam penelitian adalah $\epsilon 1=$ $0,792^{2}=0,6273$ atau $62,73 \%$.

\section{Pengujian Hipotesis}

\section{Pengujian Hipotesisis Pertama (Uji t)}

Hasil uji t dalam penelitian ini akan dijelaskan pada Tabel 5.7 berikut:

Tabel 2 Hasil Pengujian Parsial (Uji T)

\begin{tabular}{|l|c|c|c|c|c|}
\hline \multirow{2}{*}{ Variabel } & \multicolumn{2}{|c|}{$\begin{array}{c}\text { Unstandardized } \\
\text { Coefficients }(\mathbf{B})\end{array}$} & $\begin{array}{c}\text { Standardized } \\
\text { Coefficients }\end{array}$ & \multirow{2}{*}{ T } & \multirow{2}{*}{ Sig. } \\
\cline { 2 - 4 } & $\mathbf{B}$ & Std. Error & Beta & & \\
\hline (Constant $)$ & 1,872 & 0,351 & - & 5,328 & 0,000 \\
\hline Kesadaran Merek $\left(\mathrm{X}_{1}\right)$ & 0,273 & 0,084 & 0,336 & 3,274 & 0.002 \\
\hline Pengalaman Merek $\left(\mathrm{X}_{2}\right)$ & 0,311 & 0,087 & 0,369 & 3.591 & 0.001 \\
\hline
\end{tabular}

Sumber: Data diolah kembali

Hasil pengujian yang diperoleh dalam penelitian ini terlihat pada Tabel 2 di atas, variabel kesadaran merek (X1) memiliki tingkat signifikansi t sig. $(0,05 \geq 0,002)$. Hal ini menunjukan bahwa hipotesis pertama yang menyatakan kesadaran merek (X1) berpengaruh signifikan terhadap preferensi merek (Y) pada produk parfum merek Vitalis di Universitas Tadulako dengan pengaruh sebesar 11,29\%. Jadi, disimpulkan bahwa hipotesis pertama dapat diterima dan terbukti.

\section{Pengujian Hipotesis Kedua (Uji t)}

Hasil pengujian yang diperoleh, variabel pengalaman merek (X2) memiliki tingkat signifikansi t sig. $(0,05 \geq 0,001)$. Hal ini menunjukan bahwa hipotesis kedua yang menyatakan pengalaman merek (X2) berpengaruh signifikan terhadap preferensi merek (Y) pada produk parfum merek Vitalis di Universitas Tadulako dengan pengaruh sebesar 13,62\%. Jadi, disimpulkan bahwa hipotesis kedua pula dapat diterima dan terbukti. 
Pembahasan Hasil Penelitian

\section{Pengaruh Kesadaran Merek (X1) terhadap Preferensi Merek (Y) pada Produk Parfum Merek} Vitalis di Universitas Tadulako

Hasil pengujian dalam penelitian ini menunjukkan bahwa variabel kesadaran merek (X1) memberikan pengaruh positif terhadap preferensi merek $(\mathrm{Y})$ pada produk parfum merek Vitalis di Universitas Tadulako memiliki tingkat signifikansi t sig. $(0,05 \geq 0,002)$. Dengan demikian, kesadaran merek (X1) berpengaruh signifikan terhadap preferensi merek $(\mathrm{Y})$ pada produk parfum merek Vitalis di Universitas Tadulako.

Adapun indikator kesadaran merek yang memiliki nilai mean tertinggi yaitu kemampuan untuk mengingat dan mengenali model varian (X15) dan ciri khas merek (X16) dengan nilai interval sangat baik/sangat penting sekaligus menjadi indikator dengan nilai tertinggi dalam variabel kesadaran merek (X1) dengan nilai skor 349, dan nilai mean 4,25.

\section{Pengaruh Pengalaman Merek (X2) terhadap Preferensi Merek (Y) pada Produk Parfum Merek Vitalis di Universitas Tadulako}

Hasil pengujian dalam penelitian ini menunjukkan bahwa variabel pengalaman merek (X2) memberikan pengaruh positif terhadap preferensi merek (Y) pada produk parfum merek Vitalis di Universitas Tadulako memiliki tingkat signifikansi $\mathrm{t}$ sig. $(0,05 \geq 0,001)$. Dengan demikian, pengalaman merek $(\mathrm{X} 2)$ berpengaruh signifikan terhadap preferensi merek (Y) pada produk parfum merek Vitalis di Universitas Tadulako. Adapun indikator pengalaman merek yang memiliki nilai mean tertinggi yaitu indikator sentuhan (X22) dengan nilai skor 346 dan nilai mean 4,22.

\section{KESIMPULAN DAN SARAN}

\section{Kesimpulan}

Berdasarkan hasil data yang telah diuraikan di atas dari hasil penelitian yang dilakukan di

Universitas Tadulako, maka dapat ditarik kesimpulan sebagai berikut:

1. Variabel kesadaran merek berpengaruh positif dan signifikan terhadap preferensi merek pada produk parfum merek Vitalis di Universitas Tadulako, dengan tingkat signifikansi t sig. $(0,05$ $\geq 0,002$ ) dan berpengaruh sebesar $11,29 \%$.

2. Variabel pengalaman merek berpengaruh positif dan signifikan terhadap preferensi merek pada produk parfum merek Vitalis di Universitas Tadulako, dengan tingkat signifikansi t sig. $(0,05 \geq 0,001)$ dan berpengaruh sebesar $13,62 \%$.

\section{Saran}

Adapun saran-saran yang dapat diberikan oleh penulis sebagai berikut:

1. Disaran kepada manajemen perusahaan PT. Unza Vitalis untuk tetap konsisten dalam peningkatan, baik mutu dan kualitas produk parfumnya, mengingat bahwa sebagian besar responden telah menyadari dengan baik dan mendapatkan pengalaman lebih melalui banyak hal dalam aktivitasnya dengan produk parfum Vitalis.

2. Bagi Perusahaan PT. Unza Vitalis kedepannya untuk lebih memaksimalkan beberapa keinginan konsumennya melalui produk parfum yang mampu digemari khalayak umum.

3. Untuk penelitian yang akan datang, diharapkan untuk lebih memperhatikan kekurangan dan keterbatasan dalam penelitian, menambah variabel penelitian yang memengaruhi preferensi merek misalnya kepercayaan merek, attribut produk, ekuitas merek, faktor pribadi, persepsi kualitas, asosiasi merek, untuk cakupan yang lebih luas dalam perolehan data yang akurat, penambahan objek yang diteliti, sehingga hasil yang akan dicapai memberikan konstribusi nilai lebih baik.

\section{REFERENSI}

Adam, P. Rosida, 2008. Perilaku Konsumen (Implementasi Pada Produk Teh). Diterbitkan oleh Tadulako University Press, Palu.

Adisaputro, Gunawan, 2014. Manajemen Pemasaran (Analisis Untuk Perancangan Strategi Pemasaran). Penerbit Unit Penerbit dan Percetakan, Yogyakarta. 
Islamiyah F.

Alma, Buchari, 2014. Manajemen Pemasaran Dan Pemasaran Jasa. Edisi Revisi, Cetakan Ke-11, Penerbit Alfabeta, Bandung.

Assauri, Sofjan, 2013. Manajemen Pemsaran (Dasar, Konsep Dan Strategi). Edisi Ke-1, Penerbit PT. Rajagrafindo Persada, Jakarta

Brakus, J Josko, Bernd H Schmitt dan Lia Zarantonello, (2009). Brand Experience : What is it? How is it Meassured? Does it Affect Loyalty?. Journal of Marketing, Vol.73, No.2, pp. Diakses Pada 10 Oktober 2016.

Ebrahim, Shawky Reham, 2013. A Study of Brand Preference: An Experiential View. A Thesis submitted for the degree of Doctor of Philosophy, Brunel Business School. Diakses Pada 15 November 2016.

Fongana, Andreas. (2009). Pengaruh Brand Prefence Terhadap Repeat Purchase Pada Produk Shampo Anti Ketombe Clear For Man Di Surabaya. Universitas petra : surabaya. Diakses pada 14 November 2016.

Ghozali, Imam, 2006. Aplikasi Analisis Multivariate Bagi Program SPSS. Cetakan ke-4, Ghozali, Imam, 2007. Aplikasi Analisis Multivariate Bagi Program SPSS. Badan Penerbit UNDIP, Semarang.

Khan, Muhammad Asif dan Cecile Bozzo, 2012. Connection Between Self Concept And Brand Preference And The Role Of Product Usage. Diakses Pada 15 November 2016.

Kotler, Philip dan Kevin Lane Keller, 2009. Manajemen Pemasaran. Edisi Ke-13 Jilid I dan II, Terjemahan Bob Sabran, Penerbit PT. Erlangga, Jakarta..

Purwanto, Edi, Djumilah Hadiwidjojo dan Kusuma Ratnawati, 2011. Preferensi Merek Sebagai Pemediasi Pengaruh Kesadaran Merek dan Asosiasi Merek terhadap Loyalitas Konsumen. Jurnal Aplikasi Manajemen Volume 11 Nomor 2. ISSN 1693-5241. Diakses Pada 10 Oktober 2016.

Rangkuti, Fredy, 2009. The Power Of Brand. Penerbit PT. Gramedia Pustaka Utama, Jakarta.

Riduwan dan Engkos Achmad Kuncoro, 2007. Cara Menggunakan dan Memaknai Analisis Jalur (Path Analysis). Penerbit Alfabeta, Bandung.

Singarimbun, Masri dan Sofian Effendi. 2008. Metode Penelitian Survai. Edisi Revisi, Penerbit LP3ES, Jakarta.

Sugiyono, 2014. Memahami Penelitian Kualitatif. Cetakan Ke-10, Penerbit Alfabeta, Bandung.

Sumodiningrat, Gunawan, (2001). Pengantar Ekonometrika. Yogyakarta, BPFE.

Sunyoto, Danang, 2015. Perilaku Konsumen dan Pemasaran: (Panduan Riset Sederhana Untuk Mengenai Konsumen ), Cetakan Ke-1, Penerbit CAPS

(Center Of Academic Publishing Service), Yogyakarta.

Zulganef, 2013. Metode Penelitian Sosial dan Bisnis. Penerbit Graha Ilmu, Yogyakarta. 